\title{
Molecular Dynamics Simulation to Investigate the Interaction of Asphaltene and Oxide in Aggregate
}

\author{
Rui Li, ${ }^{1}$ Hui Du, ${ }^{2}$ Zepeng Fan, ${ }^{1}$ and Jianzhong Pei ${ }^{1}$ \\ ${ }^{1}$ School of Highway, Chang'an University, Xi'an 710064, China \\ ${ }^{2}$ School of Transportation Engineering, Southeast University, Nanjing 210096, China \\ Correspondence should be addressed to Jianzhong Pei; peijianzhong@126.com
}

Received 4 July 2015; Accepted 4 January 2016

Academic Editor: Amritendu Roy

Copyright (c) 2016 Rui Li et al. This is an open access article distributed under the Creative Commons Attribution License, which permits unrestricted use, distribution, and reproduction in any medium, provided the original work is properly cited.

\begin{abstract}
The asphalt-aggregate interface interaction (AAI) plays a significant role in the overall performances of asphalt mixture, which is caused due to the complicated physicochemical processes and is influenced by various factors, including the acid-base property of aggregates. In order to analyze the effects of the chemical constitution of aggregate on the AAI, the average structure $\mathrm{C}_{65} \mathrm{H}_{74} \mathrm{~N}_{2} \mathrm{~S}_{2}$ is selected to represent the asphaltene in asphalt and magnesium oxide $(\mathrm{MgO})$, calcium oxide $(\mathrm{CaO})$, aluminium sesquioxide $\left(\mathrm{Al}_{2} \mathrm{O}_{3}\right)$, and silicon dioxide $\left(\mathrm{SiO}_{2}\right)$ are selected to represent the major oxides in aggregate. The molecular models are established for asphaltene and the four oxides, respectively, and the molecular dynamics (MD) simulation was conducted for the four kinds of asphaltene-oxide system at different temperatures. The interfacial energy in MD simulation is calculated to evaluate the AAI, and higher value means better interaction. The results show that interfacial energy between asphaltene and oxide reaches the maximum value at $25^{\circ} \mathrm{C}$ and $80^{\circ} \mathrm{C}$ and the minimum value at $40^{\circ} \mathrm{C}$. In addition, the interfacial energy between asphaltene and $\mathrm{MgO}$ was found to be the greatest, followed by $\mathrm{CaO}, \mathrm{Al}_{2} \mathrm{O}_{3}$, and $\mathrm{SiO}_{2}$, which demonstrates that the AAI between asphalt and alkaline aggregates is better than acidic aggregates.
\end{abstract}

\section{Introduction}

Studies have shown that asphalt pavement damage phenomenon has a strong dependency upon asphalt-aggregate interfacial nature. If the bond between asphalt and aggregate is weak, then the interface between asphalt and aggregate is prone to failure, which results in the early damage of pavement. Therefore, many methods were used to study the interface between asphalt and aggregate in different perspectives. Elphingstone [1] proposed that the surface free energy is an effective approach to predict the fatigue and moisture properties of mixture, and adhesion process of aggregate plays an important role. Tan et al. [2] tested the phase angle and complex shear modulus of matrix asphalt and asphalt mastic by dynamic shear rheometer, and the asphalt-aggregate interaction capabilities were evaluated by K.Ziegel-B parameter. Cheng et al. [3] measured the surface free energy of different asphalt and aggregates and calculated the adhesion work of asphalt and reactive aggregates with and without water.
Bhasin et al. [4] proposed quantifying the free energy of the surface of asphalt-aggregate adhesion energy, and the results have shown that the same type of aggregate and bitumen adhesion between the energies has significant difference. To sum up, on the asphalt-aggregate interface studies have been largely analyzed from the experimental point of view. However, the experimental results were affected by many factors, in the dynamic shear rheological experiments; powderbinder ratio had greater impact on the test results, and how to determine the best powder-binder ratio is a problem. While aggregate composition is complex, powder, and mixed into the asphalt, mastic asphalt does not characterize asphalt-aggregate interface behavior. In the surface energy calculation, measurement results on the final great influence, different methods may result in different surface energy, resulting in a larger difference in the results.

In recent years, with the improvement of computer hardware and the perfection of related theory, molecular dynamics (MD) have become the effective means to study a complex 
system from the molecular level [5], the effective methods for the deep understanding of asphaltene adsorption characteristics, and the interaction mechanism of the interface from the microscopic view. At present, the domestic and foreign scholars mostly from the angle of test studied asphalt with aggregate interface area properties, and the computer simulation research is less. As a result, the MD method asphaltaggregate interface behavior of asphalt mixture's research has the vital significance.

Based on the molecular dynamics calculation, we can simulate the asphalt-aggregate interfacial behavior. In four components of asphalt, asphaltene molecular mass is bigger and has stronger polarity and the asphaltenes content has a great impact on the properties of asphalt [6]. Asphaltene is fused aromatic ring system as the core, with a number of different alkyl chains linked structure, with $\mathrm{N}, \mathrm{S}$, and $\mathrm{O}$ heteroatoms, not soluble in nonpolar molecules of the corresponding normal alkanes soluble in benzene and toluene matter [7]. The composition, structure, and morphology of the asphaltene are very complex. In the study, the average molecular model is often used to replace the chemical structure [8]. Rogel [9] proposed a representative average asphaltene molecular structure model for the study of this paper. According to the composition of aggregate analysis, aggregates content of more oxides was analyzed, the remaining content of less neglected ones. The asphalt-oxide interface model based on dynamics simulation of the interfacial energy and adsorption configuration, which can quantitatively point out the ability of the main oxides in asphalt and aggregate interface interaction, for further understanding the mechanism of adhesion between asphalt and aggregate, is of great significance.

\section{Computer Simulation Theory}

2.1. Basic Theory. Calculations were conducted with Accelrys Materials Studio software package in this study and this method relies mainly on Newtonian mechanics to simulate the movement of molecular systems, the samples are taken in different states of the molecular system, and the configuration of the system is integrated. The thermodynamic quantities and other macroscopic properties are further calculated based on the results of the integration configuration.

COMPASS is selected for force field simulation, and the potential energy function form is shown as follows:

$$
\begin{aligned}
E_{\text {total }}= & \sum_{\text {bond }} E_{b}(b)+\sum_{\text {angle }} E_{\theta}(\theta)+\sum_{\text {dihedral }} E_{\phi}(\phi) \\
& +\sum_{\text {out-of-plane }} E_{\chi}(\chi)+\sum_{\text {cross }} E(b, \theta, \phi)+E_{\text {coulomb }} \\
& +E_{\mathrm{vdw}} .
\end{aligned}
$$

In (1), the preceding five letters are bonding interaction of which the potential energy function contains bond lengths, bond angles, dihedral angles, plane, and cross-term; $b, \theta, \phi$, and $\chi$ are expressed as bond lengths, bond angles, dihedral angles, and off-plane vibration; the next two letters are nonbonding interactions which are electrostatic interaction

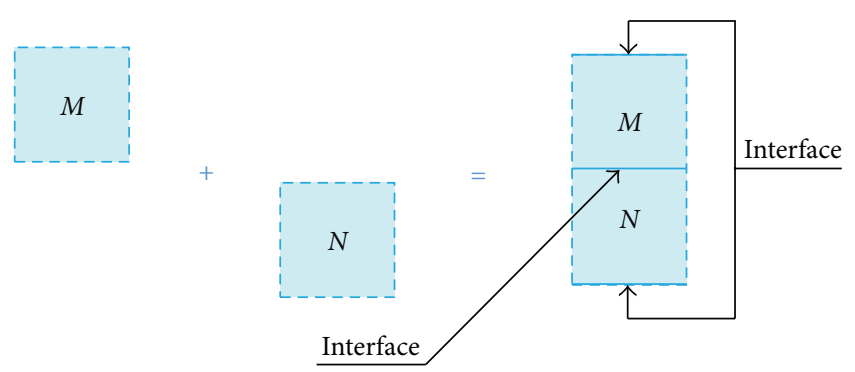

FIgURE 1: Schematic diagram of the interfacial energy.

$E_{\text {coulomb }}$ and van der Waals interaction $E_{\mathrm{vdw}}$, respectively.

$E_{\text {coulomb }}$ and $E_{\mathrm{vdw}}$ are calculated by the following:

$$
\begin{aligned}
E_{\text {coulomb }} & =\sum_{i>j} \frac{q_{i} q_{j}}{r_{i j}}, \\
E_{\mathrm{vdw}} & =\sum \varepsilon_{i j}\left[2\left(\frac{r_{i j}^{0}}{r_{i j}}\right)^{9}-3\left(\frac{r_{i j}^{0}}{r_{i j}}\right)^{6}\right] .
\end{aligned}
$$

In (2) and (3), $i$ and $j$ represent different atoms; $q$ is atomic charge; $r$ is the distance of different atomic; $\varepsilon$ is potential well depth.

The interface model is composed of three layers. The first layer is oxide, the second layer is asphaltene, and the third layer is vacuum, eliminating the impact of the cyclical interaction between the particles resulting from double counting.

The molecular dynamics simulation of the canonical ensemble (NVT) is completed by Discover module. According to the set temperature, the temperature is controlled by Andersen thermostat, the initial rate of each molecule is randomly generated by the Maxwell-Boltzmann distribution, Newton's equation of motion is calculated by Velocity Verlet algorithm, and the van der Waals interaction and Coulomb interaction are calculated by Charge Group method.

2.2. Interfacial Energy Calculation. Interfacial energy is also known as the interaction energy, the calculation method is similar to the surface energy, and the difference is that the interfacial energy reflects the bonding strength between the two materials. The interface may be between the same materials or different materials; the interfacial energy of the same material can be theoretically equal to the surface energy. The interfacial energy can be calculated as shown in Figure 1.

In Figure 1, to calculate the interfacial energy between materials $M$ and $N$, the interface model is constructed as shown in the right of Figure 1. The model is calculated in temperature $T$ and system NVT by molecular dynamics until the system reaches a steady state; the energy of the model is $E_{\text {total }}$. The interface models $M$ and $N$ are constructed as shown in the left of Figure 1 and calculated by molecular dynamics; the energy of the two models is $E_{M}$ and $E_{N}$, respectively. If the area of the combination surface is $A$, the interfacial energy is calculated as follows:

$$
\gamma_{\text {int }}=\frac{\left(E_{M}+E_{N}-E_{\text {total }}\right)}{2 A} .
$$




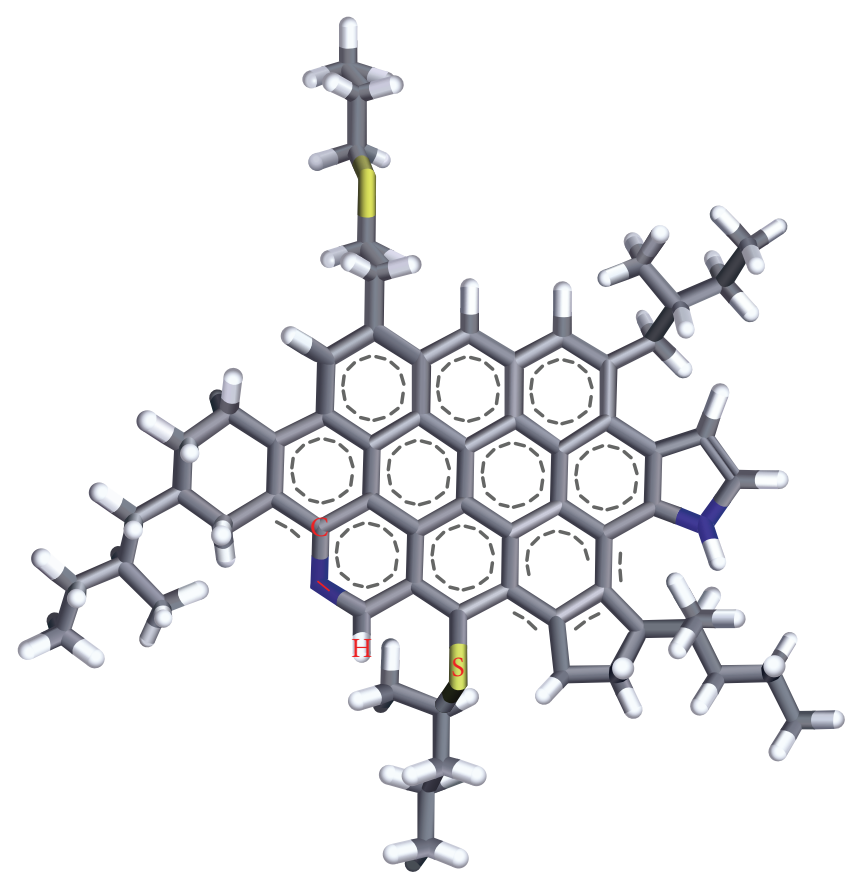

Figure 2: Average molecular structure of asphaltene.

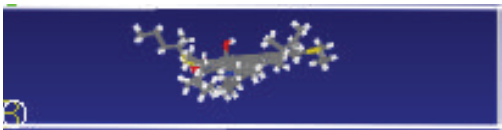

$10^{\circ} \mathrm{C}$

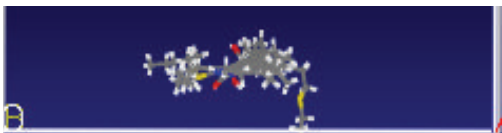

$40^{\circ} \mathrm{C}$

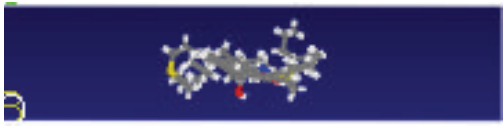

$80^{\circ} \mathrm{C}$

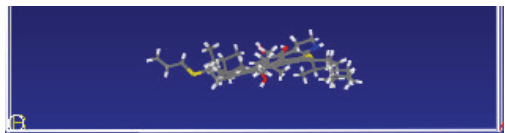

$25^{\circ} \mathrm{C}$

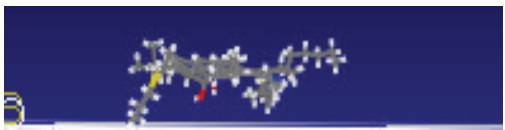

$60^{\circ} \mathrm{C}$

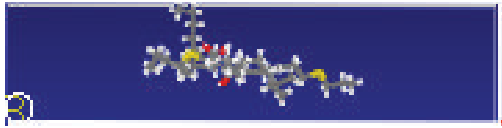

$100^{\circ} \mathrm{C}$

FIGURE 3: The configuration of asphaltene molecules in different temperature.

\section{Results and Discussion}

3.1. Asphaltene Molecular Structure Model. Since the composition and structure of the asphaltene are very complex, Rogel et al. built average molecular structure, which was standardized samples studied in the Strategic Highway Research Program (SHRP). The average structure is shown in Figure 2.

Because asphaltenes are highly polydisperse molecules, the construction is highly complex. So in the research, we used one of the average molecules. For the simulation, we chose the COMPASS force field. For the asphaltene, the target density was set to $1 \mathrm{~g} / \mathrm{cm}^{3}$, constructing the configuration of asphaltene system. In order to analyze the temperature dependence of the asphaltene system, six different temperatures were chosen: $10^{\circ} \mathrm{C}(283.15 \mathrm{~K}), 25^{\circ} \mathrm{C}(298.15 \mathrm{~K}), 40^{\circ} \mathrm{C}(313.15 \mathrm{~K})$, $60^{\circ} \mathrm{C}(333.15 \mathrm{~K}), 80^{\circ} \mathrm{C}(353.15 \mathrm{~K})$, and $100^{\circ} \mathrm{C}(373.15 \mathrm{~K})$, and the results are shown in Figure 3.

\subsection{Oxide Molecular Structure Model}

3.2.1. Selection of Representative Oxides. To simulate aggregate, we used 10 chemical compositions of aggregate (M1, $M 2, \ldots, M 10)$ suggested by Ozkahraman and Işik [10] (as seen in Figure 4). The chemical composition of aggregate is $\mathrm{SiO}_{2}>\mathrm{CaO}>\mathrm{Al}_{2} \mathrm{O}_{3}>\mathrm{MgO}>\mathrm{Fe}_{2} \mathrm{O}_{3}>\mathrm{NaO}>\mathrm{K}_{2} \mathrm{O}$.

Therefore, the simulation is mainly focused on the four oxides which are $\mathrm{SiO}_{2}, \mathrm{CaO}, \mathrm{Al}_{2} \mathrm{O}_{3}$, and $\mathrm{MgO}$. 


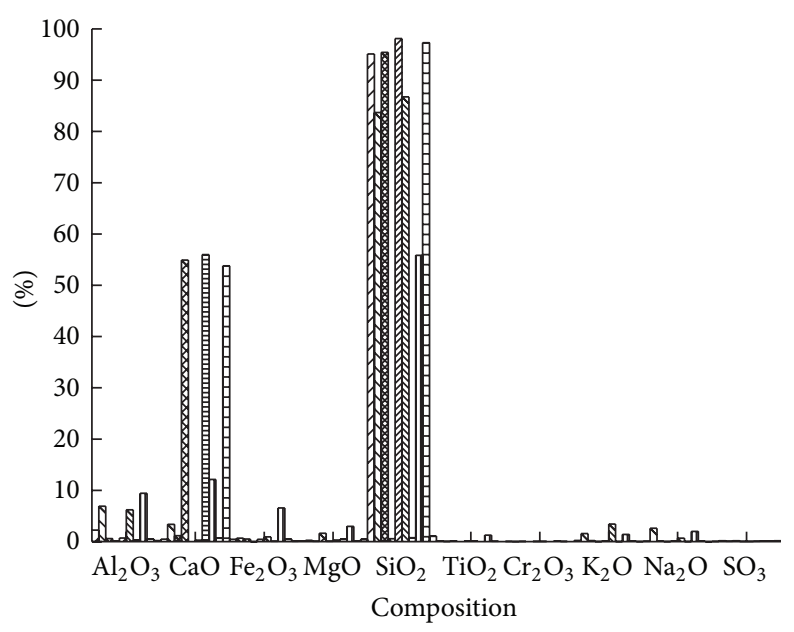

\begin{tabular}{|c|c|}
\hline ZIA M1 & $M 6$ \\
\hline MV M2 & 豆 $M 7$ \\
\hline 网 & 血血 $M 8$ \\
\hline M4 & Е M9 \\
\hline Шய1M M5 & 世曲 $M 10$ \\
\hline
\end{tabular}

FIgURE 4: The chemical composition of aggregates.

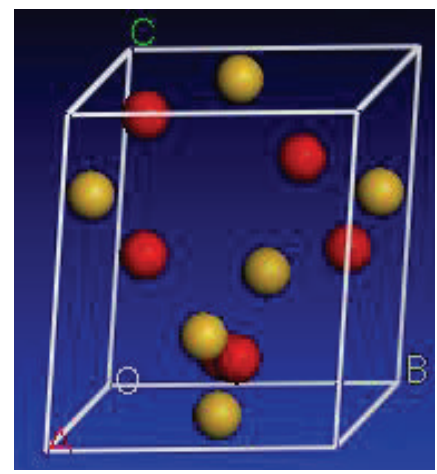

$\mathrm{SiO}_{2}$

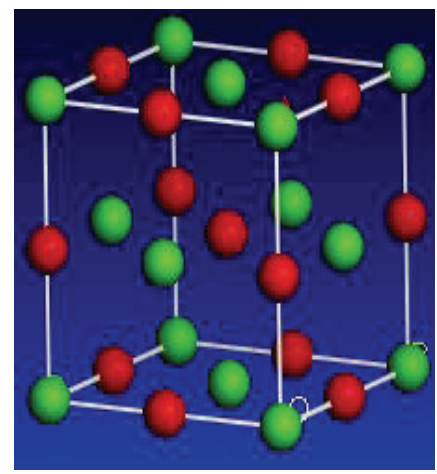

$\mathrm{CaO}$

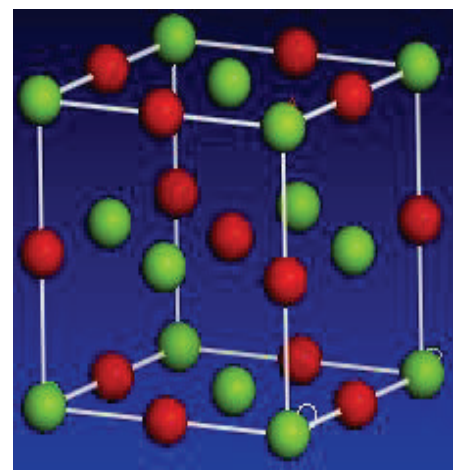

$\mathrm{MgO}$

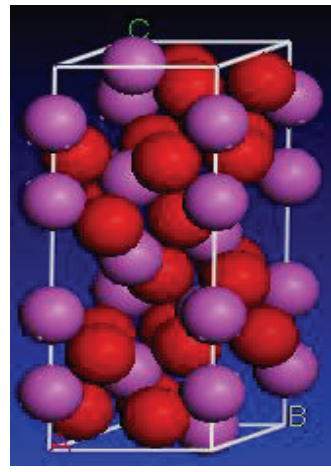

$\mathrm{Al}_{2} \mathrm{O}_{3}$

FIGURE 5: Four kinds of oxide molecular cell structure.

3.2.2. Building Oxide Molecular Cell. By the molecular dynamics software that comes with the unit cell model of oxide molecules, molecular cell structure of oxide is formed after importing the unit cell model, as shown in Figure 5.

3.2.3. Building Oxide Supercell. Based on the molecular cell above, the cell is intercepted by section 001 . Secondly, the force field is assigned to each atom of cell. In the paper, the force field is COMPASS. The energy of cell is minimized by the Minimize module of Discover. Finally, the oxide supercell structure is built by the supercell module of Build which is composed of $5 \times 5$ matrix. For example, the process of building supercell structure of $\mathrm{SiO}_{2}$ is shown in Figure 6 .

\subsection{The Interaction of Asphaltene and Oxide}

3.3.1. Creating of Asphaltene/Oxide Interface. Interface model is composed of three layers. Layer 1 is oxide, layer 2 is asphaltene, and the last layer is $30 \AA$ thick vacuum layer. According the depiction earlier, the three-layer interface structure was formed. For example, the asphaltene/ $\mathrm{SiO}_{2}$ interface model of $25^{\circ} \mathrm{C}$ is shown in Figure 7.

3.3.2. Dynamic Simulation Interface of Asphaltene/Oxide. As shown in the interface model in Figure 7, molecular dynamic simulation was then conducted in order to equilibrate systems further. The temperature is set and maintained constant by Andersen thermostat; the initial rate of molecular cell structure is randomly generated by the Maxwell-Boltzmann distribution. The Velocity Verlet algorithm is used to solve Newton's equation of motion. The van der Waals interaction and the Coulomb interaction are calculated by Charge Group method. The intermolecular interaction is corrected by an average density approximation. The system was simulated under NVT conditions with velocity rescaling, which was used for 2000 ps with a time step of $1.0 \mathrm{fs}$ to dissipate high energy interactions between molecules. 


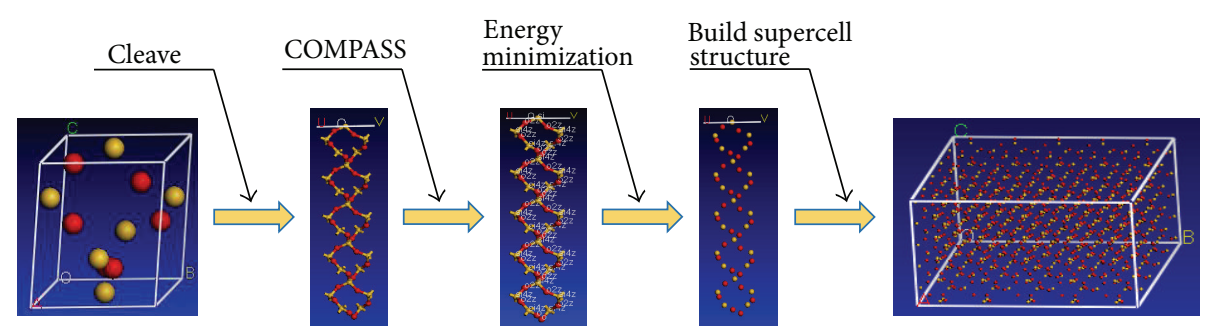

FIGURE 6: The process of building supercell structure.

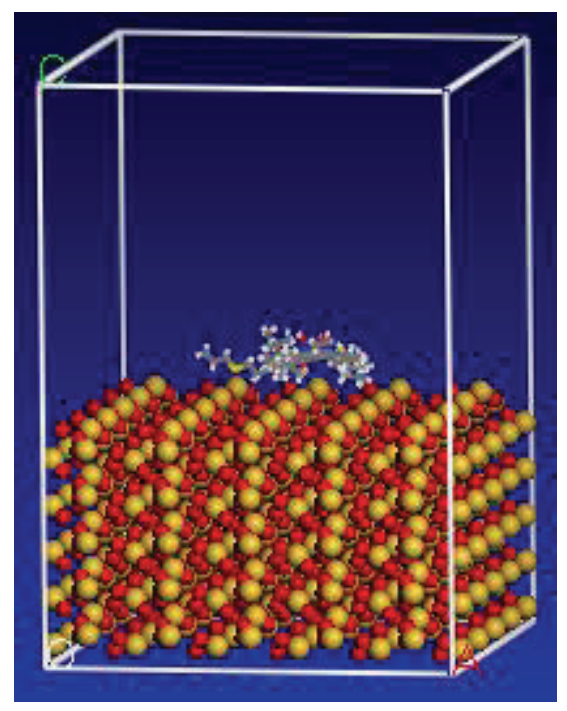

Figure 7: Asphaltene/ $/ \mathrm{SiO}_{2}$ interface model.
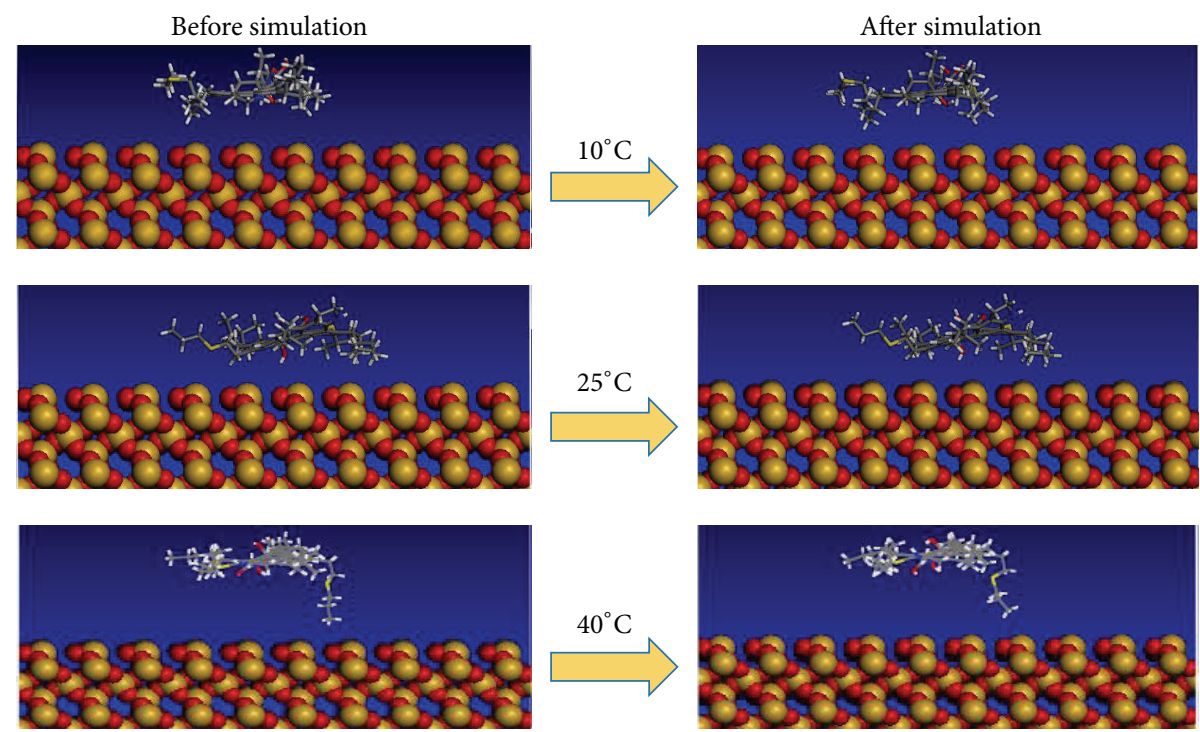

FIGURE 8: The interface configuration of asphaltene/ $\mathrm{SiO}_{2}\left(10-40^{\circ} \mathrm{C}\right)$.

MD simulation of four-group interface model was performed for temperatures of $10^{\circ} \mathrm{C}(283.15 \mathrm{~K}), 25^{\circ} \mathrm{C}(298.15 \mathrm{~K})$, $40^{\circ} \mathrm{C}(313.15 \mathrm{~K}), 60^{\circ} \mathrm{C}(333.15 \mathrm{~K}), 80^{\circ} \mathrm{C}(353.15 \mathrm{~K})$, and $100^{\circ} \mathrm{C}$ $(373.15 \mathrm{~K})$. The results are shown in Figures 8-15.
As shown in the four interface configurations, the asphaltene molecular structures change in varying degree after the simulation. The asphaltene molecular structure moves closer to the oxide surface. Comparing the four kinds of interface 

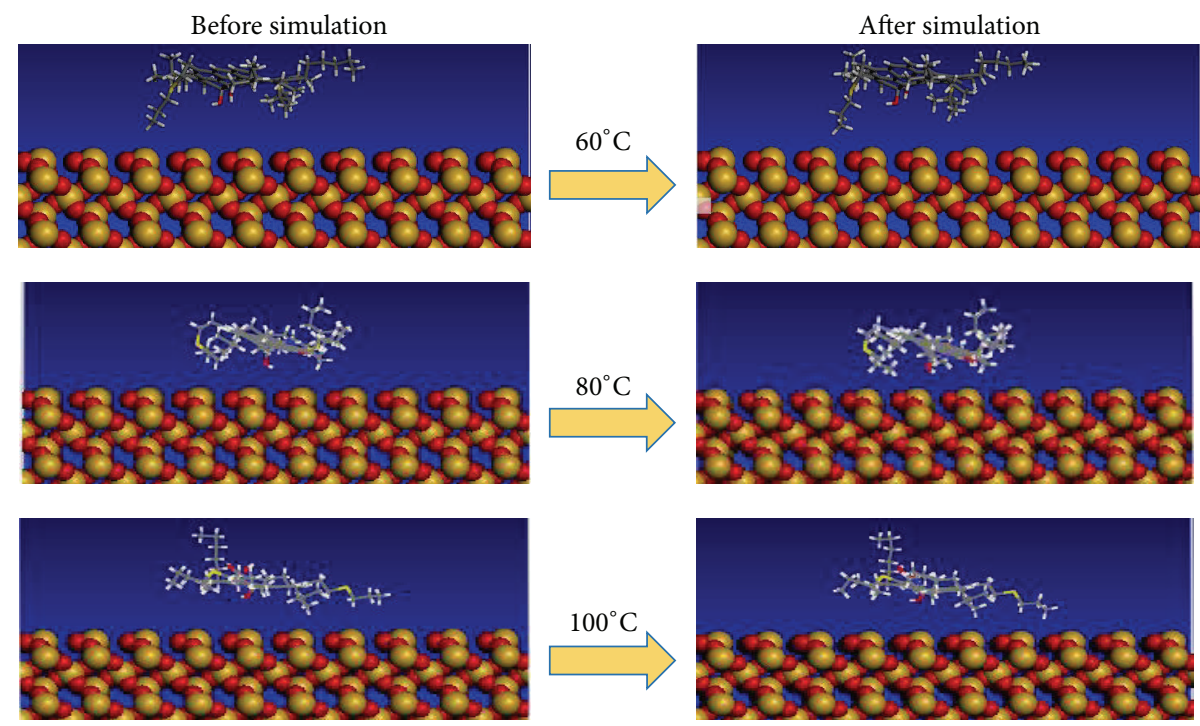

FIGURE 9: The interface configuration of asphaltene/ $\mathrm{SiO}_{2}\left(60-100^{\circ} \mathrm{C}\right)$.
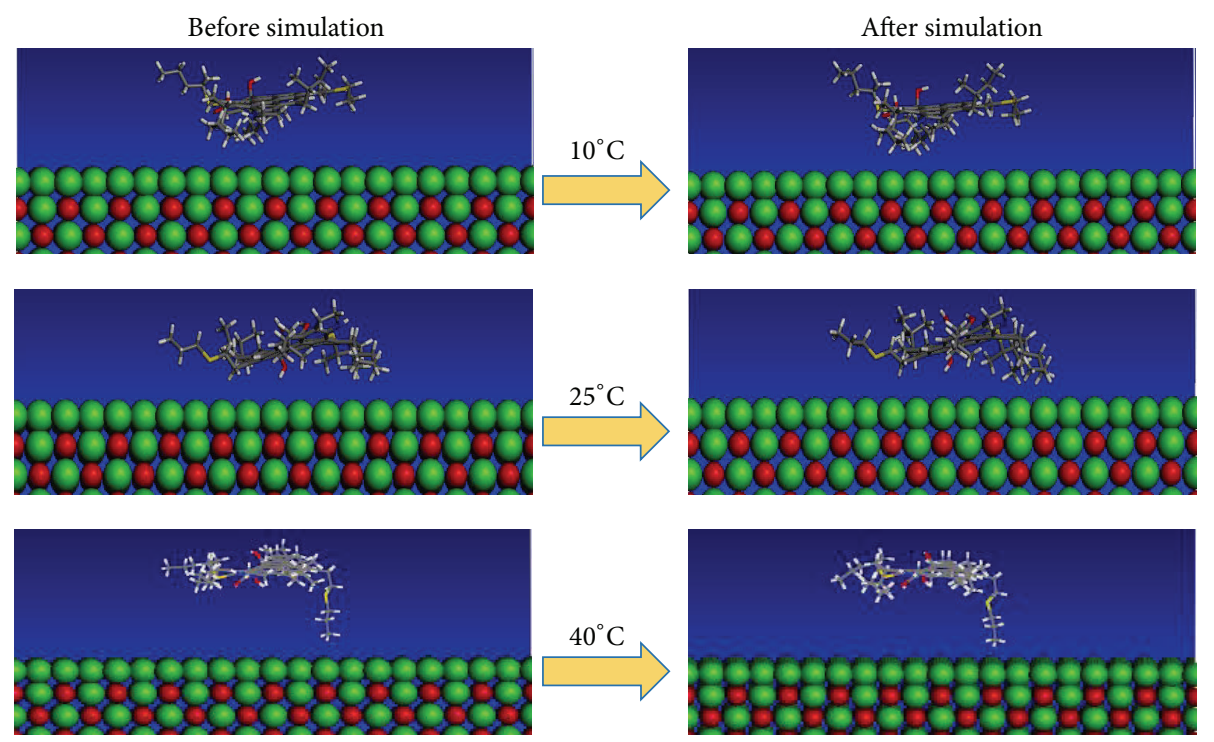

Figure 10: The interface configuration of asphaltene/ $\mathrm{CaO}\left(10-40^{\circ} \mathrm{C}\right)$.

configuration, it is difficult to evaluate the interaction between asphaltene and oxides accurately. For the fixed interface configuration, it is almost impossible to distinguish whether the interaction changes with temperature. Therefore, the interfacial energy is introduced to evaluate the interaction more precisely.

3.3.3. The Calculation of Interfacial Energy. The interfacial energy can be calculated according to the following:

$$
\gamma_{\text {int }}=\frac{\left(E_{\text {polymer }}+E_{\text {surface }}-E_{\text {total }}\right)}{2 A} .
$$

The four-interface model size is $49.000 \times 49.000 \times$ $26.38067 \AA$. So the interfacial energy equation can be simplified as follows:

$$
\gamma_{\text {int }}^{\prime}=\left(E_{\text {polymer }}+E_{\text {surface }}-E_{\text {total }}\right) .
$$

After the molecular dynamics simulation, the four kinds of interfacial energy are shown in Tables 1 and 2.

The interfacial energy of asphaltene $/ \mathrm{SiO}_{2}$ varies from $2.22 E+01$ to $2.09 E+02 \mathrm{~kJ} / \mathrm{mol}$ within the temperature range of $10^{\circ} \mathrm{C}$ to $100^{\circ} \mathrm{C}$; the calculated variation ranges of asphaltene $/ \mathrm{CaO}$, asphaltene $/ \mathrm{MgO}$, and asphaltene $/ \mathrm{Al}_{2} \mathrm{O}_{3}$ within the same temperature range are $7.44 E+02$ to $1.00 E+03 \mathrm{~kJ} / \mathrm{mol}$, 

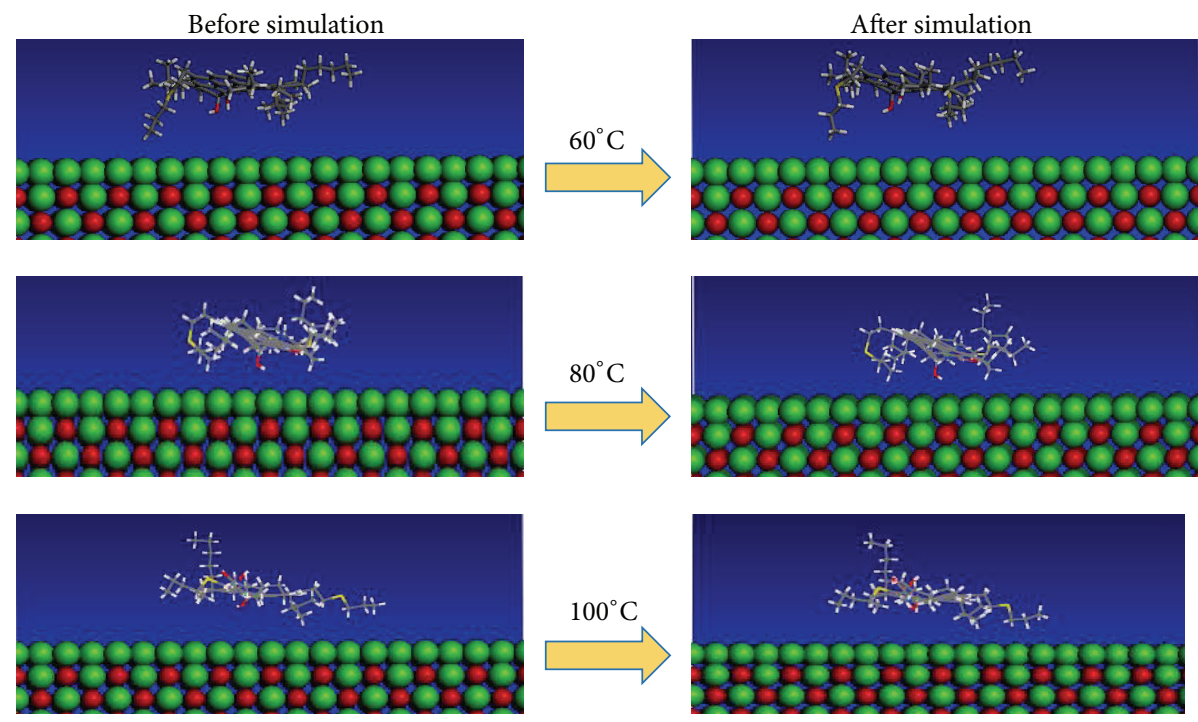

Figure 11: The interface configuration of asphaltene/ $\mathrm{CaO}\left(60-100^{\circ} \mathrm{C}\right)$.
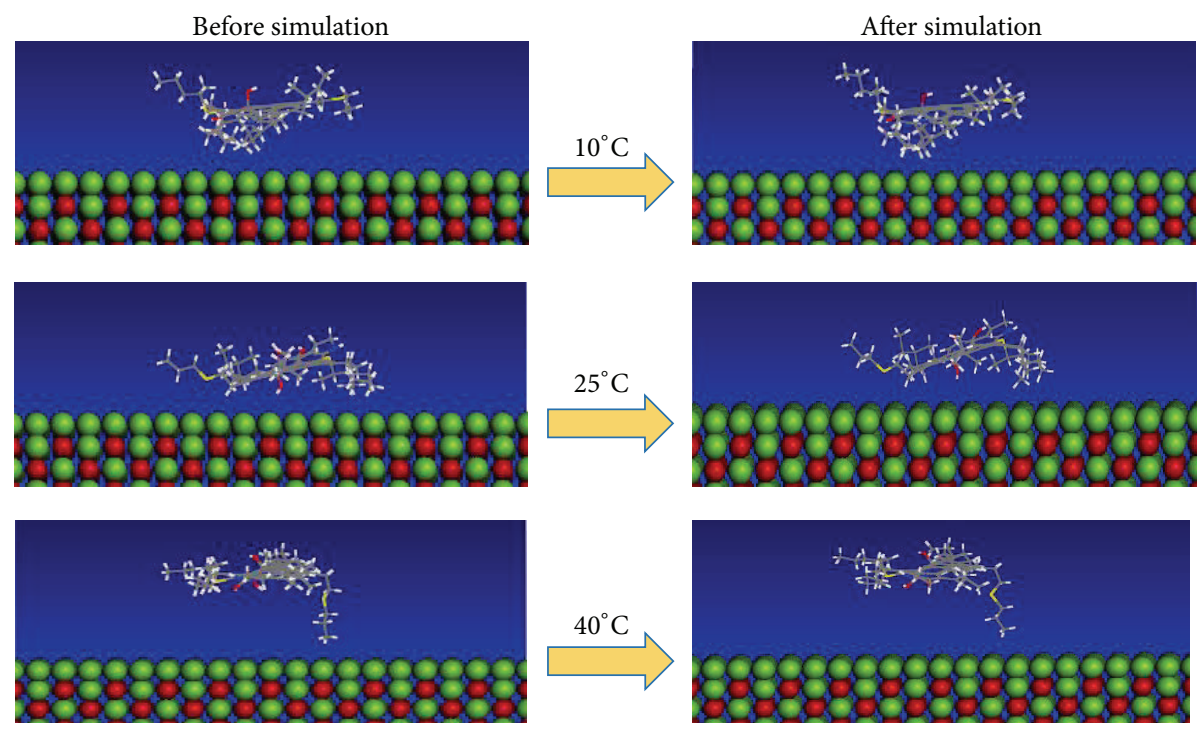

FIGURE 12: The interface configuration of asphaltene/ $\mathrm{MgO}\left(10-40^{\circ} \mathrm{C}\right)$.

TABLE 1: Asphaltene/ $\mathrm{SiO}_{2}$ and asphaltene/CaO.

\begin{tabular}{|c|c|c|c|c|c|}
\hline & Temp. $\left({ }^{\circ} \mathrm{C}\right)$ & $E_{\text {total }}(\mathrm{kJ} / \mathrm{mol})$ & $E_{\text {polymer }}(\mathrm{kJ} / \mathrm{mol})$ & $E_{\text {surface }}(\mathrm{kJ} / \mathrm{mol})$ & $E_{\text {Interface }}(\mathrm{kJ} / \mathrm{mol})$ \\
\hline \multirow{6}{*}{ Asphaltene $/ \mathrm{SiO}_{2}$} & 10 & $9.03 E+06$ & $3.63 E+02$ & $9.03 E+06$ & $2.22 E+01$ \\
\hline & 25 & $9.03 E+06$ & $3.83 E+02$ & $9.03 E+06$ & $2.09 E+02$ \\
\hline & 40 & $9.03 E+06$ & $3.73 E+02$ & $9.03 E+06$ & $3.25 E+01$ \\
\hline & 60 & $9.03 E+06$ & $3.72 E+02$ & $9.03 E+06$ & $3.88 E+01$ \\
\hline & 80 & $9.03 E+06$ & $3.83 E+02$ & $9.03 E+06$ & $1.36 E+02$ \\
\hline & 100 & $9.03 E+06$ & $3.85 E+02$ & $9.03 E+06$ & $1.31 E+02$ \\
\hline \multirow{6}{*}{ Asphaltene/CaO } & 10 & $-1.57 E+06$ & $3.71 E+03$ & $-1.57 E+06$ & $8.99 E+02$ \\
\hline & 25 & $-1.57 E+06$ & $3.69 E+03$ & $-1.57 E+06$ & $9.63 E+02$ \\
\hline & 40 & $-1.57 E+06$ & $3.68 E+03$ & $-1.57 E+06$ & $7.44 E+02$ \\
\hline & 60 & $-1.57 E+06$ & $3.87 E+03$ & $-1.57 E+06$ & $8.51 E+02$ \\
\hline & 80 & $-1.57 E+06$ & $3.83 E+03$ & $-1.57 E+06$ & $1.00 E+03$ \\
\hline & 100 & $-1.57 E+06$ & $3.81 E+03$ & $-1.57 E+06$ & $8.13 E+02$ \\
\hline
\end{tabular}



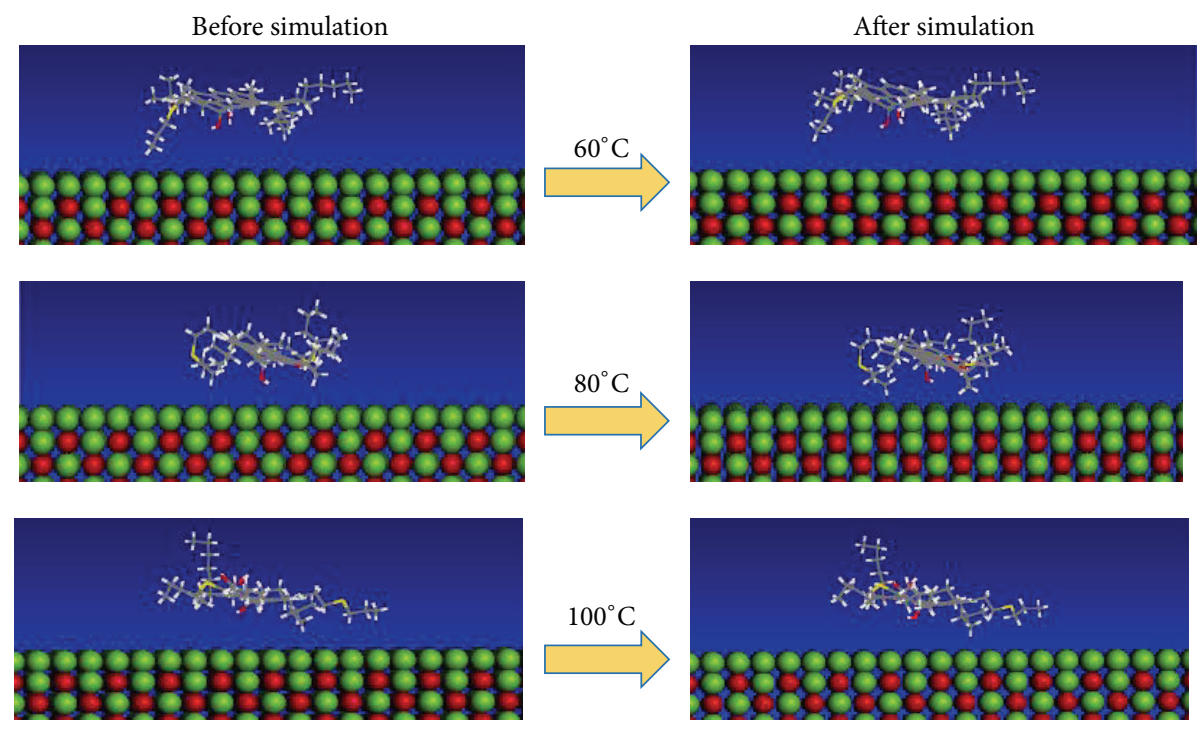

FIgURE 13: The interface configuration of asphaltene $/ \mathrm{MgO}\left(60-100^{\circ} \mathrm{C}\right)$.
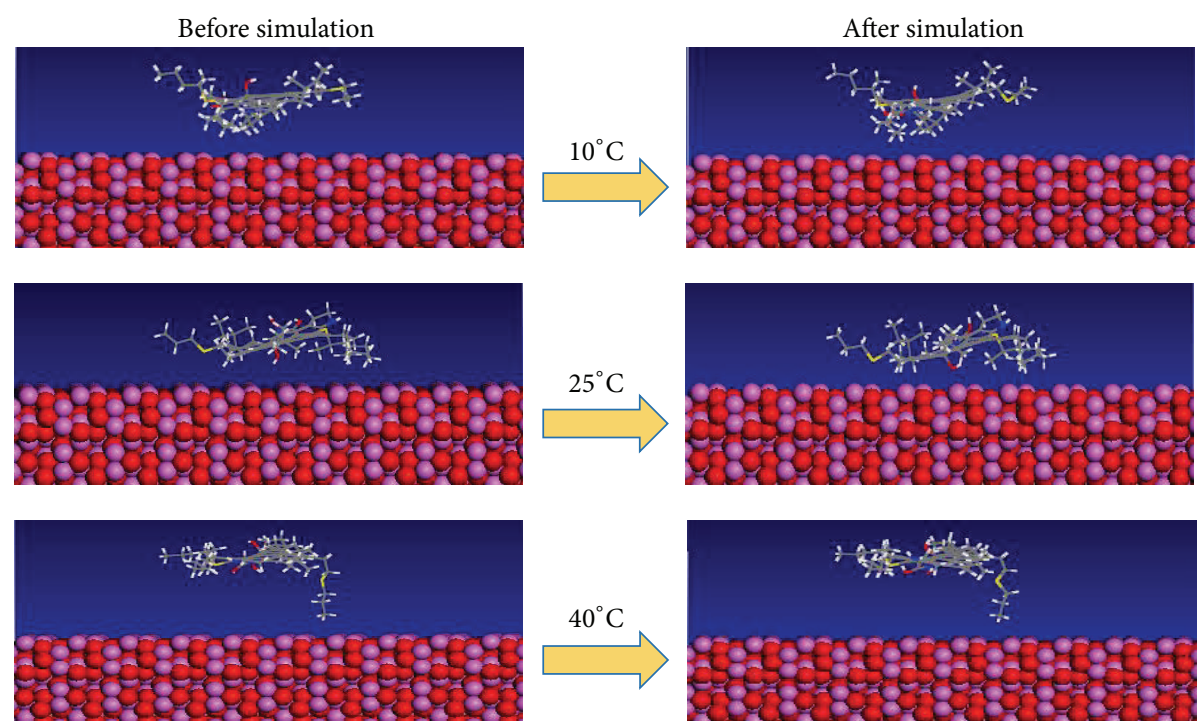

FIGURE 14: The interface configuration of asphaltene/ $\mathrm{Al}_{2} \mathrm{O}_{3}\left(10-40^{\circ} \mathrm{C}\right)$.

TABLE 2: Asphaltene/MgO and asphaltene $/ \mathrm{Al}_{2} \mathrm{O}_{3}$.

\begin{tabular}{|c|c|c|c|c|c|}
\hline & Temp. $\left({ }^{\circ} \mathrm{C}\right)$ & $E_{\text {total }}(\mathrm{kJ} / \mathrm{mol})$ & $E_{\text {polymer }}(\mathrm{kJ} / \mathrm{mol})$ & $E_{\text {surface }}(\mathrm{kJ} / \mathrm{mol})$ & $E_{\text {Interface }}(\mathrm{kJ} / \mathrm{mol})$ \\
\hline \multirow{6}{*}{ Asphaltene/MgO } & 10 & $-2.61 E+06$ & $3.71 E+03$ & $-2.61 E+06$ & $1.67 E+03$ \\
\hline & 25 & $-2.61 E+06$ & $3.79 E+03$ & $-2.61 E+06$ & $1.79 E+03$ \\
\hline & 40 & $-2.61 E+06$ & $3.73 E+03$ & $-2.61 E+06$ & $1.61 E+03$ \\
\hline & 60 & $-2.61 E+06$ & $3.76 E+03$ & $-2.61 E+06$ & $1.61 E+03$ \\
\hline & 80 & $-2.61 E+06$ & $3.76 E+03$ & $-2.61 E+06$ & $1.68 E+03$ \\
\hline & 100 & $-2.61 E+06$ & $3.81 E+03$ & $-2.61 E+06$ & $1.63 E+03$ \\
\hline \multirow{6}{*}{ Asphaltene/ $\mathrm{Al}_{2} \mathrm{O}_{3}$} & 10 & $-2.01 E+07$ & $3.75 E+03$ & $-2.01 E+07$ & $4.61 E+02$ \\
\hline & 25 & $-2.01 E+07$ & $3.72 E+03$ & $-2.01 E+07$ & $4.32 E+02$ \\
\hline & 40 & $-2.01 E+07$ & $3.92 E+03$ & $-2.01 E+07$ & $1.19 E+02$ \\
\hline & 60 & $-2.01 E+07$ & $3.98 E+03$ & $-2.01 E+07$ & $3.10 E+02$ \\
\hline & 80 & $-2.01 E+07$ & $3.97 E+03$ & $-2.01 E+07$ & $6.43 E+02$ \\
\hline & 100 & $-2.01 E+07$ & $3.87 E+03$ & $-2.01 E+07$ & $2.71 E+02$ \\
\hline
\end{tabular}



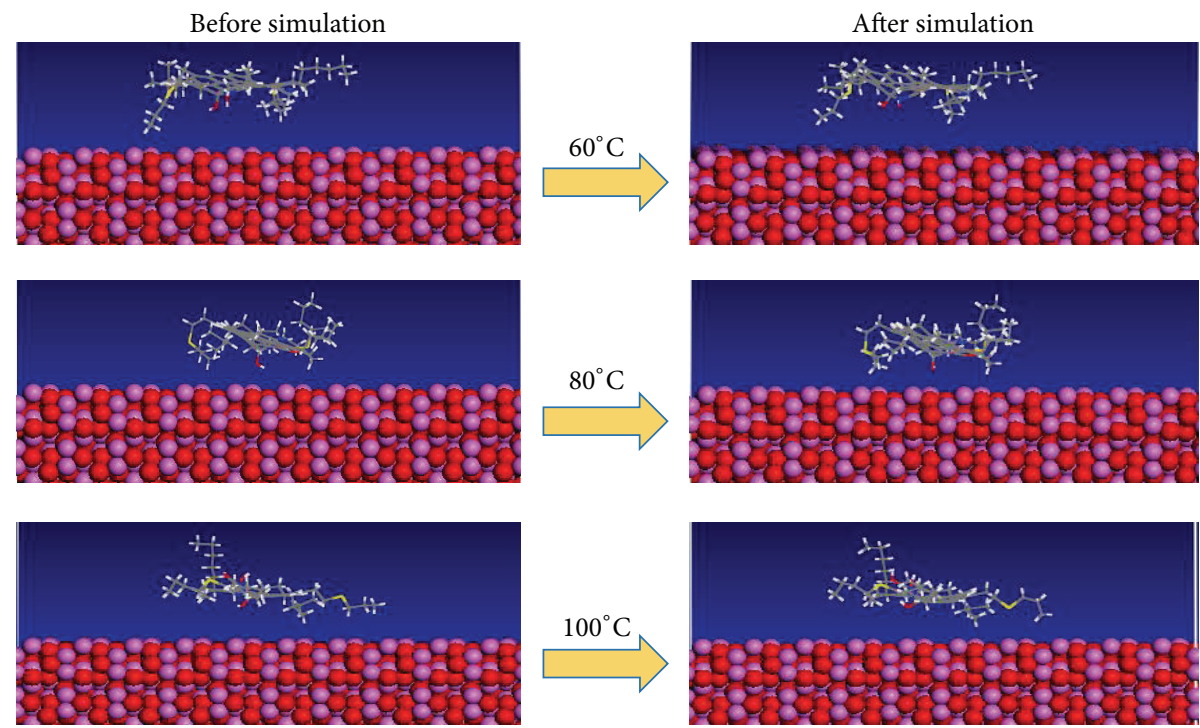

FIGURE 15: The interface configuration of asphaltene $/ \mathrm{Al}_{2} \mathrm{O}_{3}\left(60-100^{\circ} \mathrm{C}\right)$.

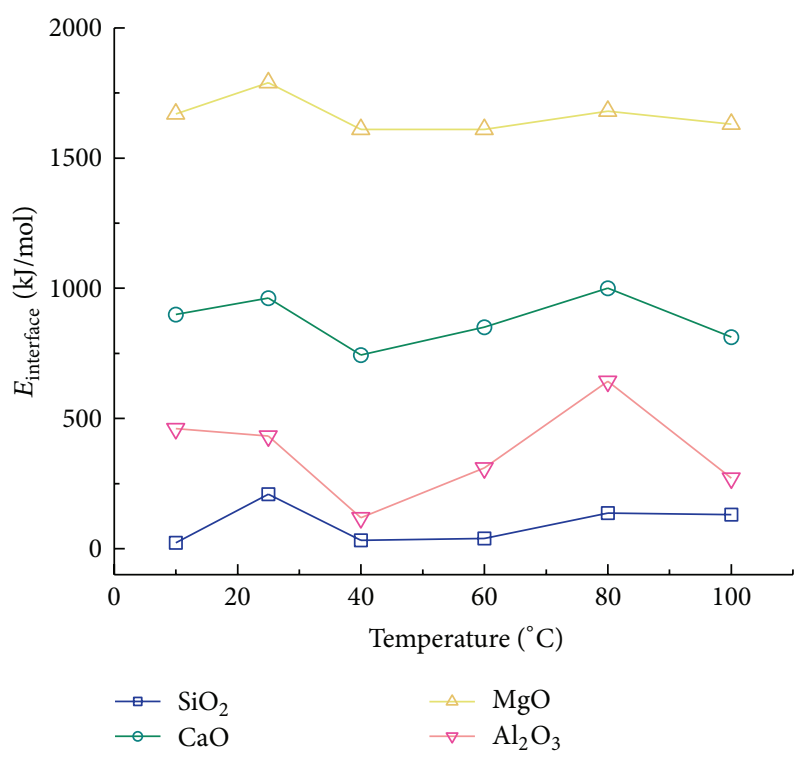

FIGURE 16: The interfacial energy with different temperature.

$1.61 E+03$ to $1.79 E+03 \mathrm{~kJ} / \mathrm{mol}$, and $1.19 E+02$ to $6.43 E+$ $02 \mathrm{~kJ} / \mathrm{mol}$, respectively. Further, the interfacial energy was plotted in Figure 16.

As shown in Figure 16, the four kinds of interfacial energy reach the extreme twice at $25^{\circ} \mathrm{C}$ and $80^{\circ} \mathrm{C}$ which indicates stronger interaction between asphaltene and oxides. Within the temperature range of $10^{\circ} \mathrm{C}$ to $100^{\circ} \mathrm{C}$, the interaction capability ranking of the four oxides to asphaltene is as follows: $\mathrm{MgO}>\mathrm{CaO}>\mathrm{Al}_{2} \mathrm{O}_{3}>\mathrm{SiO}_{2}$.

\section{Conclusion}

The interaction and the interfacial energy between asphaltene and four kinds of oxides $\left(\mathrm{MgO}, \mathrm{CaO}, \mathrm{Al}_{2} \mathrm{O}_{3}\right.$, and $\left.\mathrm{SiO}_{2}\right)$ under temperature range from $10^{\circ} \mathrm{C}$ to $100^{\circ} \mathrm{C}$ were analyzed by virtue of molecular dynamic simulations and the following conclusions can be made: the interaction between asphaltene and oxides reaches strongest level at the temperature of $25^{\circ} \mathrm{C}$ and $80^{\circ} \mathrm{C}$ and reaches weakest level at the temperature of $40^{\circ} \mathrm{C}$. It could be concluded according to the calculation results of the interfacial energy that the interfacial energy between asphaltene and four kinds of oxides ranges from $2.22 E+$ $01 \mathrm{~kJ} / \mathrm{mol}$ to $1.79 \mathrm{E}+03 \mathrm{~kJ} / \mathrm{mol}$ within the temperature range of $10^{\circ} \mathrm{C}$ to $100^{\circ} \mathrm{C}$. In this temperature range, the interaction capability ranking of the four oxides to asphaltene is as follows: $\mathrm{MgO}>\mathrm{CaO}>\mathrm{Al}_{2} \mathrm{O}_{3}>\mathrm{SiO}_{2}$.

\section{Conflict of Interests}

The authors declare that there is no conflict of interests regarding the publication of this paper.

\section{Acknowledgments}

This work is supported by the National Natural Science Foundation of China (Grant nos. 51408048 and 51378037), the Key Program for International Science and Technology Cooperation Projects of Shaanxi province (Grant nos. 2012KW09 and 2014KW10-03), the China Postdoctoral Science Foundation (Grant nos. 2015M570805 and 2015M582592), the Fundamental Research Funds for the Central Universities of Chang'an University (Grant nos. 310821153502 and 310821152005), and the Research Fund for the Doctoral Program of Higher Education of China (Grant no. 20120205120010).

\section{References}

[1] G. M. Elphingstone, Adhesion and cohesion in asphalt-aggregate systems [Ph.D. thesis], Texas A\&M University, College Station, Tex, USA, 1997. 
[2] Y.-Q. Tan, J.-T. Wu, X.-M. Li, and L. Ji, "Evaluation indexes for interaction capability of asphalt and aggregate," Journal of Harbin Institute of Technology, vol. 41, no. 7, pp. 81-84, 2009.

[3] D. Cheng, D. N. Little, R. L. Lytton, and J. C. Holste, "Use of surface free energy properties of the asphalt-aggregate system to predict moisture damage potential," Journal of the Association of Asphalt Paving Technologists, vol. 71, pp. 59-88, 2002.

[4] A. Bhasin, E. Masad, D. Little, and R. Lytton, "Limits on adhesive bond energy for improved resistance of hot-mix asphalt to moisture damage," Transportation Research Record, vol. 1970, pp. 3-13, 2006.

[5] R. Notman and T. R. Walsh, "Molecular dynamics studies of the interactions of water and amino acid analogues with quartz surfaces," Langmuir, vol. 25, no. 3, pp. 1638-1644, 2009.

[6] K. J. Leontaritis, J. O. Amaefule, and R. E. Charles, "Systematic approach for the prevention and treatment of formation damage caused by asphaltene deposition," in Proceedings of the International Symposium on Formation Damage Control, pp. 383-395, Lafayette, La, USA, February 1992.

[7] Y.-F. Li, G.-W. Lu, W. Sun et al., "Study on the molecular dynamics of petroleum-derived asphaltene aggregate," Acta Petrolei Sinica (Petroleum Processing Section), vol. 23, no. 4, pp. 25-31, 2007.

[8] P. Srivastava, W. G. Chapman, and P. E. Laibinis, "Molecular dynamics simulation of oxygen transport through $n$-alkanethiolate self-assembled monolayers on gold and copper," The Journal of Physical Chemistry B, vol. 113, no. 2, pp. 456-464, 2009.

[9] E. Rogel, "Studies on asphaltene aggregation via computational chemistry," Colloids and Surfaces A: Physicochemical and Engineering Aspects, vol. 104, no. 1, pp. 85-93, 1995.

[10] H. T. Ozkahraman and E. C. Işik, "The effect of chemical and mineralogical composition of aggregates on tensile adhesion strength of tiles," Construction and Building Materials, vol. 19, no. 4, pp. 251-255, 2005. 

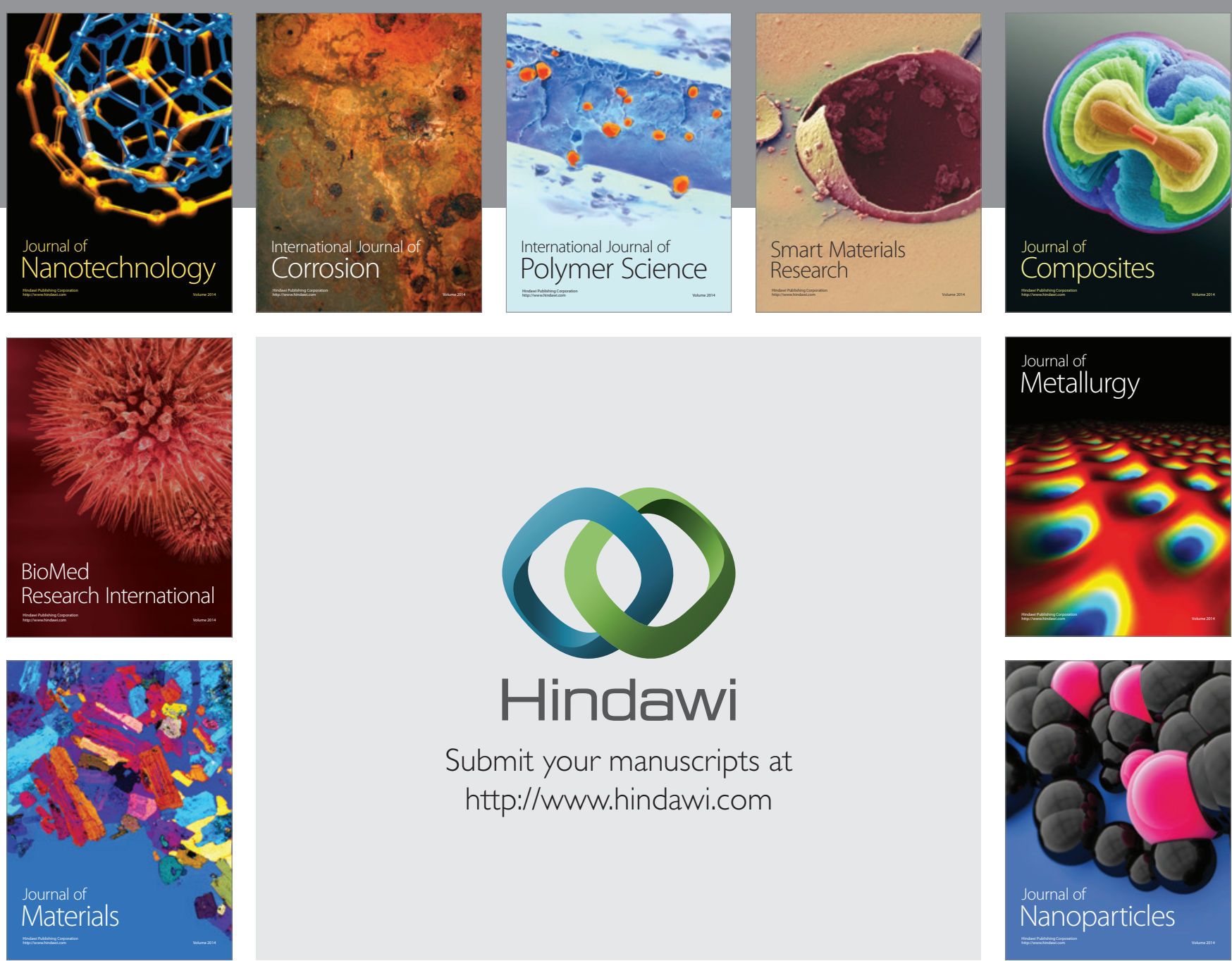

\section{Hindawi}

Submit your manuscripts at

http://www.hindawi.com

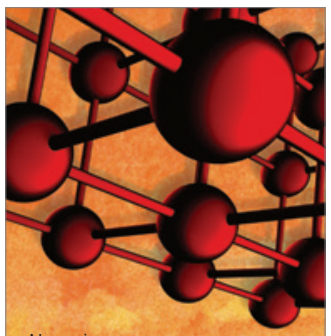

Materials Science and Engineering
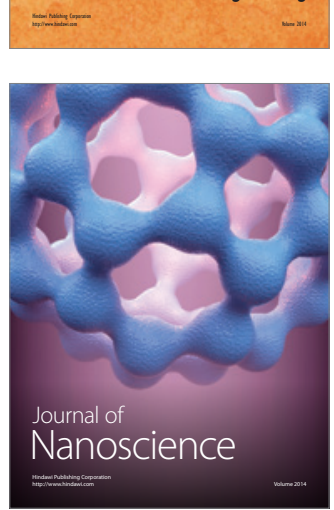
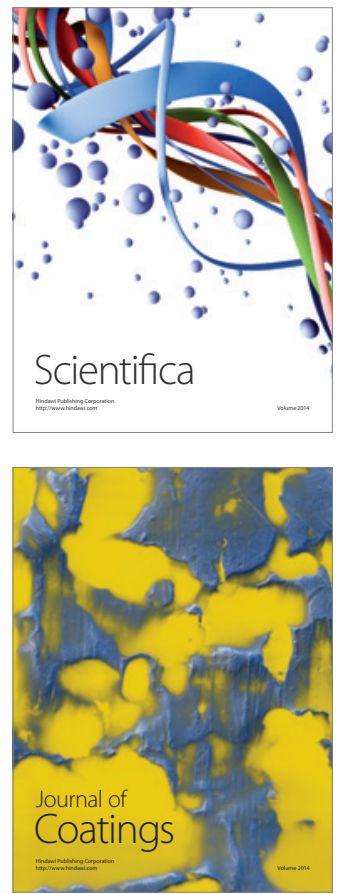
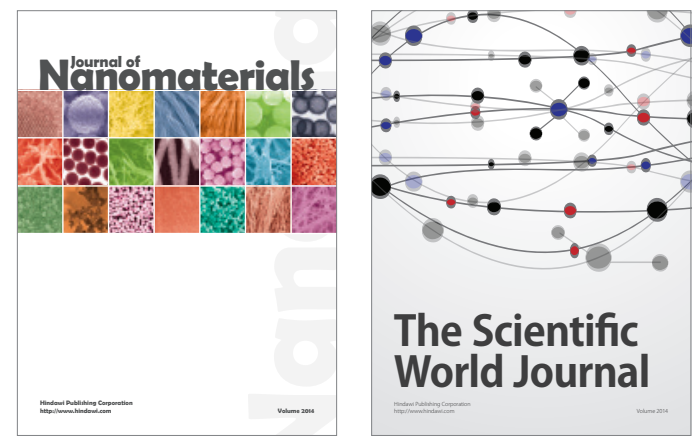

The Scientific World Journal
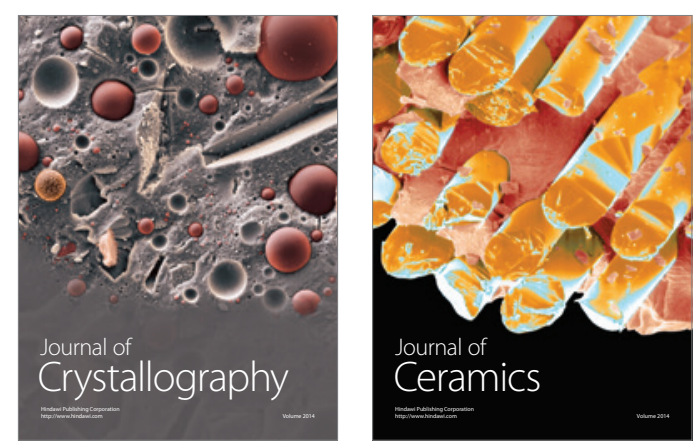
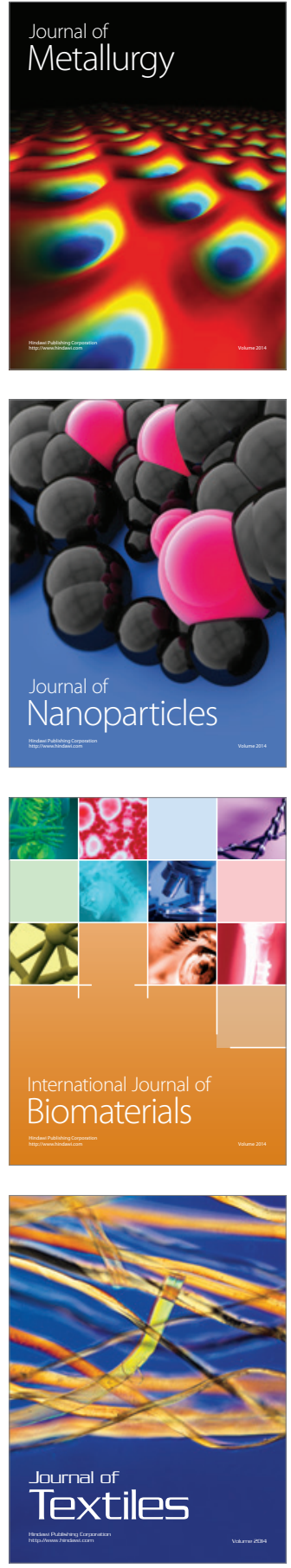